Reviu Akuntansi dan Bisnis Indonesia, Vol. 2 No. 1, Hlm: 26-38, Juli 2018

Website: http://journal.umy.ac.id/index.php/rab

\title{
Pengaruh Infor Masi Akuntansi Terhadap Pengungkapan Corporate Social Responsibility (CSR) Dengan Ukuran Dewan Komisaris Sebagai Variabel Moderating : Studi pada Perusahaan Manufaktur yang Terdaftar di BEI Tahun 2013-2016
}

\author{
Arofa Nafia Anindita; Arum Indrasari \\ Program Studi Akuntansi Universitas Muhammadiyah Yogyakarta
}

I N F O A R T I K E L

Kata Kunci:

Profitabilitas, Likuiditas,

Leverage, Ukuran Dewan

Komisaris, Pengungkapan CSR

Jenis Artikel:

Penelitian Empiris

Correspondence:

arum.indrasari@umy.ac.id

\author{
A B S T R A K
}

Penelitian ini bertujuan untuk mengetahui: 1) Profitabilitas berpengaruh positif terhadap pengungkapan Corporate Social Responsibility, 2) Likuiditas berpengaruh positif terhadap pengungkapan Corporate Social Responsibility, 3) Leverageberpengaruh negatif terhadap pengungkapan Corporate SocialResponsibility, 4) Ukuran dewan komisaris dapat memoderasi hubungan profitabilitas dengan pengungkapan Corporate Social Responsibility, 5) Ukuran dewan komisaris dapat memoderasi hubungan likuiditas dengan pengungkapan Corporate Social Responsibility, dan6) Ukuran dewan komisaris dapat memoderasi hubungan leverage dengan pengungkapan Corporate Social Responsibility.Penelitian ini dilakukan pada laporan keuangan yang diterbitkan di Bursa Efek Indonesia(BEI) dengan menggunakan 182 perusahaan manufaktur sebagai sampel yang digunakan. Pengambilan sampel menggunakan metode purposive sampling. Teknik pengumpulan data dari laporan tahunan di Bursa Efek Indonesia (BEI) dan analisis data menggunakan uji statistik deskriptif, uji asumsi klasik terdiri dari uji normalitas, uji autokorelasi, uji multikolinearitas, uji Heteroskedastisitasdan uji hipotesis menggunakan Moderator Regression Analysis(MRA).Hasil penelitian: 1) Profitabilitas tidak berpengaruh positif terhadap pengungkapan Corporate Social Responsibility, 2) Likuiditas tidak berpengaruh positif terhadap pengungkapan Corporate Social Responsibility, 3) Leverageberpengaruh negatif terhadap pengungkapan Corporate Social Responsibility, 4) Ukuran dewan komisaris tidak mampu memoderasi hubungan profitabilitasdengan pengungkapan Corporate Social Responsibility, 5) Ukuran dewan komisaris tidak mampu memoderasi hubungan likuiditas dengan pengungkapan Corporate Social Responsibility, dan 6) Ukuran dewan komisaris tidak mampu memoderasi hubungan leverage dengan pengungkapan Corporate Social Responsibility.

(C) 2019 RAB. Published by Universitas Muhammadiyah Yogyakarta

\section{PENDAHULUAN}

Corporate Social Responsibility (CSR) atau tanggung jawab sosial perusahaan yaitu suatu gagasan yang menjadikan perusahaan tidak hanya mementingkan aspek keuangan saja dan 
mengasingkan diri dari lingkungan masyarakat dimana perusahaan menjalankan operasinya, namun juga harus mementingkan aspek sosial dan beradaptasi dengan lingkungannya (Daniri, 2008). CSR adalah suatu bentuk kepedulian entitas pada masyarakat khususnya masyarakat yang berada di lingkungan dimana perusahaan didirikan. Walaupun tujuan utama perusahaan yaitu mendapatkan keuntungan, namun tidak bisa dilepaskan dari masyarakat (Gunawan dan Suhartini, 2008). Perusahaan melakukan CSR memiliki alasan, salah satunya yaitu untuk mematuhi peraturan yang telah ada. Pemerintah mengeluarkan Undang-Undang No. 40 Tahun 2007 pasal 74 tentang Perseroan Terbatas yang mewajibakan perseroan yang bergerak di bidang mengenai Sumber Daya Alam (SDA) dalam upaya untuk melaksanakan tanggung jawab sosial dan lingkungan di sekitarnya. Menurut UU No. 40 Tahun 2007 pasal 1 ayat 3 menyatakan bahwa tanggung jawab sosial dan lingkungan merupakan sebuah komitmen pada perusahaan dalam peranan pembangunan ekonomi dan berkelanjutan dan meningkatkan kualitas kehidupan dan lingkungan yang memberikan manfaat bagi suatu perusahaan, komunitas setempat, serta masyarakat pada umum di lingkungan perusahaan. Peraturan perundang-undangan yang lain yang menyangkut CSR yaitu UU No. 25 Tahun 2007 tentang Penanaman Modal yang menyebutkan bahwa setiap penanam modal memiliki kewajiban melaksanakan tanggung jawab sosial perusahaan. Undang-Undang tersebut dikeluarkan mempunyai tujuan, disamping untuk mendorong perusahaan untuk melakukan pengungkapan CSR, yang juga dilakukan untuk memenuhi tuntutan dalam menerapkan Good Corporate Governance (GCG) untuk tata kelola perusahaan yang baik.

Menurut UU No.40 Tahun 2007 pelaksanaan GCG harus didukung oleh struktur Corporate Governance yang mana struktur tersebut terdiri dari Dewan Komisaris, Dewan Direksi, dan Rapat Umum Pemegang Saham (RUPS). Dewan Komisaris memiliki tugas dalam pengawasan kebijakan direksi dalam menjalankan perusahaannya serta dapat memberikan nasihat-nasihat kepada direksi. Dewan komisaris memiliki wewenang untuk memberikan pengaruh yang cukup kuat untuk menekan manajemennya untuk mengungkapkan informasi mengenai tanggungjawab sosial perusahaan. Pelaksanaan CSR selalu memiliki kaitan dengan penerapan GCG. Pelaksanaan GCG memiliki tujuan untuk mendorong timbulnya kesadaran dan tanggung jawab perusahaan terhadap masyarakat dan lingkungan sekitar perusahaan (Rosmasita, 2007). Banyak perusahaan menjalankan CSR dikarenakan beberapa hal yaitu dengan perusahaan menjalankan CSR bisa meningkatkan citra perusahaan, dapat memberikan keberuntungan bagi perusahaan, dan dapat menjamin berlangsungnya hidup perusahaan. Adanya penerapan CSR, perusahaan menyadari bahwa CSR merupakan bagian dari strategi bisnis perusahaan (Warta Ekonomi, 2006). Banyak perusahaan publik di Indonesia yang telah menerapkan praktik pengungkapan CSR pada laporan tahunannya. Perusahaan memiliki hak dalam memilih bentuk pengungkapan CSR yang sesuai dengan kebutuhan organisasinya, perusahaan sudah menyadari bahwa informasi mengenai CSR merupakan hal yang penting.

Dari beberapa penelitian terdahulu tentang faktor-faktor yang mempengaruhi pengungkapan CSR memberikan hasil yang berbeda-beda dan tidak konsisten. Adapun peneliti sebelumnya yaitu Yintayani (2011), Gray et. al (2001), dan Putri dan Christiawan (2014). Dengan ketidak konsistenan yang terjadi pada penelitian sebelumnya, maka penulis tertarik untuk meneliti ulang dengan tahun yang berbeda.

\section{TINJAUAN LITERATUR DAN PERUMUSAN HIPOTESIS}

\section{Pengaruh Profitabilitas terhadap Pengungkapan Corporate Social Responsibility (CSR)}

Profitabilitas adalah faktor yang menjadikan manajemen bebas dan fleksibel untuk melakukan pengungkapan tanggung jawab sosial kepada pemegang saham, sehingga perusahaan yang memiliki tingkat profitabilitas tinggi maka akan semakin besar pula pengungkapan informasi sosialnya (Marbun, 2008). Dengan meningkatnya profit perusahaan, maka persediaan dana untuk melakukan aktivitas pengungkapan CSR akan semakin besar pula, dikarenakan sudah tersedianya biaya pelaksanaan untuk pengungkapan CSR. 
Selain hal itu hubungan antara profitabilitas dengan pengungkapan CSR juga dilandasi oleh teori legitimasi dimana untuk mendapatkan nilai positif dan legitimasi dari masyarakat maka perusahaan harus melakukan pengungkapan CSR. Dengan adanya mekanisme corporate governance dan profitabilitas memberikan keyakinan perusahaan untuk melakukan pengungkapan CSR, berarti dengan mekanisme corporate governance dan profitabilitas yang mencukupi perusahaan tetap akan mendapatkan keuntungan yang positif, yaitu mendapatkan legitimasi dari masyarakat yang berdampak di masa yang akan datang untuk meningkatkan keuntungan perusahaan.

Ada beberapa peneliti yang telah melakukan penelitian tentang pengaruh profitabilitas terhadap CSR, diantaranya yaitu Yintayani (2011), dengan hasil yang diperoleh memberikan hasil bahwa profitabilitas berpengaruh positif terhadap CSR. Peneliti lain yang juga melakukan penelitian mengenai pengaruh profitabilitas terhadap CSR yaitu Nurkhin (2009) dan Fahrizqi (2010) memberikan hasil bahwa profitabilitas berpengaruh positif signifikan terhadap pengungkapan CSR serta penelitian yang dilakukan oleh Sudana dan Arlindania (2011) memperoleh hasil bahwa profitabilitas berpengaruh positif dan signifikan terhadap pengungkapan CSR. Maka hipotesis penelitian ini dapat dirumuskan sebagai berikut:

\section{$\boldsymbol{H}_{\boldsymbol{I}} \quad$ : Profitabilitas berpengaruh positif dan signifikan terhadap pengungkapan Corporate Social Responsibility (CSR).}

\section{Pengaruh Likuiditas Terhadap Pengungkapan Corporate Social Responsibility (CSR)}

Perusahaan yang memiliki tingkat likuiditas yang rendah harus memberikan informasi yang lebih detail untuk menjelaskan lemahnya kinerja dibandingkan dengan perusahaan dengan tingkat likuiditas tinggi (Badjuri, 2011). Biasanya para investor menjadikan likuiditas sebagai tolok ukur untuk melakukan penilaian terhadap perusahaan. Maka dari itu ketika tingkat likuiditas, perusahaan akan lebih banyak melakukan pengungkapan CSR lebih banyak, hal ini terkait dengan teori sinyal karena manajemen perusahaan ini lebih tahu mengenai kinerja internal perusahaan dibandingkan dengan investor. Ketika perusahaan memiliki tingkat likuiditas yang rendah maka investor akan memberikan nilai yang rendah kepada perusahaan dan bisa jadi melakukan pencabutan dalam investasinya, karena investor hanya akan melihat hasil akhirnya saja seperti rasiorasio keuangan, sehingga untuk mengurangi hal tersebut perusahaan melakukan pengungkapan CSR lebih banyak agar menarik investor. Informasi tersebut terkait dengan berlangsungnya kehidupan jangka panjang perusahaan sehingga harapannya jika adanya pengungkapan CSR yang banyak saat tingkat likuiditas rendah investor tetap akan mempertahankan investasinya.

Penelitian Syahrir dan Suhendra (2010), memberikan hasil bahwa likuiditas mempunyai pengaruh positif terhadap pengungkapan CSR. Serta penelitian Hussaney, et. al (2011) memberikan hasil bahwa likuiditas berpengaruh positif terhadap pengungkapan CSR. Maka perumusan hipotesis sebagai berikut:

\section{$\boldsymbol{H}_{2}$ : Likuiditas berpengaruh positif dan signifikan terhadap pengungkapan Corporate Social Responsibility (CSR).}

\section{Pengaruh Leverage Terhadap Pengungkapan Corporate Social Responsibility (CSR)}

Perusahaan dengan rasio leverage yang tinggi memiliki besar kemungkinan untuk melakukan pelanggaran terhadap perjanjian kredit sehingga perusahaan akan berusaha melaporkan laba sekarang lebih tinggi. Manajer harus melakukan pengurangan biaya-biaya, termasuk biaya pengungkapan CSR, agar laba yang dilaporkan perusahaan lebih tinggi. Terbatasnya biaya CSR menjadikan pengungkapan CSR menjadi lebih rendah atau terbatas sehingga semakin tinggi leverage suatu perusahaan akan menambah beban tetap perusahaan yang menyebabkan rendahnya 
pengungkapan CSR karena terbatas (Rawi dan Muchlish, 2010). Menurut Sembiring (2005) tingkat leverage perusahaan dapat menggambarkan resiko keuangan perusahaan. Hal ini sesuai dengan teori agensi, agar perusahaan tidak menjadi sorotan dari para debtholders, maka perusahaan dengan tingkat leverage yang tinggi akan mengurangi pengungkapan tanggung jawab sosialnya.

Beberapa peneliti yang melakukan penelitian mengenai leverage terhadap pengungkapan CSR yaitu diantaranya Belkaoui dan Karpik (1989) yang memberikan hasil bahwa leverage berpengaruh negatif terhadap pengungkapan CSR. Serta peneliti lain yaitu Kinantika (2013) memberikan hasil bahwa leverage berpengaruh negatif terhadap pengungkapan CSR. Berdasarkan penjelasan di atas, maka dapat disimpulkan hipotesis sebagai berikut:

\section{$\mathrm{H}_{3} \quad$ : Leverage berpengaruh negatif terhadap pengungkapan Corporate Social Responsibility (CSR).}

\section{Pengaruh Ukuran Dewan Komisaris Sebagai Variabel Moderating dalam Hubungan Profitabilitas dengan Corporate Social Responsibility (CSR)}

Semakin banyaknya jumlah anggota dewan komisaris, maka akan semakin mudah untuk melakukan pengendalian terhadap CEO dan pengawasan yang dilakukan akan semakin efektif. Jika dikaitkan dengan pengungkapan tanggung jawab sosial, maka tekanan terhadap manajemen juga akan semakin besar untuk mengungkapkannya (Sembiring, 2005). Dikaitkan dengan teori agensi bahwa semakin besar atau banyak jumlah dari dewan komisaris akan lebih memudahkan pelaksanaan tanggung jawab sosial perusahaan. Menurut Anggraini (2006) kaitan profitabilitas dengan pengungkapan tanggung jawab sosial telah menjadi anggapan dasar untuk mencerminkan pandangan bahwa reaksi sosial memerlukan gaya manajerial. Dengan seiring meningkatnya profit dalam perusahaan, maka persediaan dana untuk melakukan aktivitas pengungkapan CSR akan semakin besar pula. Berdasarkan pernyataan tersebut maka semakin besar jumlah anggota dewan komisaris dan semakin tinggi tingkat profitabilitas maka kemungkinan mengungkapkan tanggung jawab sosial perusahaan semakin besar. Dapat disimpulkan hipotesis sebagai berikut:

\section{$H_{4} \quad$ : Ukuran Dewan Komisaris secara signifikan dapat memoderasi hubungan antara pengaruh profitabilitas terhadap pengungkapan Corporate Social Responsibility (CSR).}

\section{Pengaruh Ukuran Dewan Komisaris Sebagai Variabel Moderating dalam Hubungan Likuiditas dengan Corporate Social Responsibility (CSR)}

Likuiditas adalah rasio untuk dapat mengetahui kemampuan suatu perusahaan dalam membayar hutang jangka pendeknya. Pengukuran likuiditas dengan menggunakan rasio lancar (Sumarsan, 2010). Perusahaan yang memiliki tingkat likuiditas yang rendah harus memberikan informasi yang lebih detail untuk menjelaskan lemahnya kinerja dibandingkan dengan perusahaan dengan tingkat likuiditas tinggi (Badjuri, 2011). Maka dari itu perusahaan akan cenderung melakukan pengungkapan CSR lebih banyak ketika likuiditas yang dihasilkan rendah, hal ini terkait dengan teori sinyal karena manajemen perusahaan ini lebih tahu mengenai kinerja internal perusahaan dibandingkan dengan investor. Investor hanya akan melihat hasil akhirnya saja seperti rasio-rasio keuangan, sehingga ketika perusahaan memiliki tingkat likuiditas yang rendah maka investor akan cenderung memberi nilai yang rendah kepada perusahaan dan bisa jadi melakukan pencabutan dalam investasinya, sehingga untuk mengurangi hal tersebut perusahaan melakukan pengungkapan CSR lebih banyak agar menarik investor.

Semakin besar jumlah anggota dewan komisaris, maka semakin mudah untuk melakukan pengendalian CEO dan pengawasan yang dilakukan semakin efektif. Ketika dikaitkan dengan pengungkapan tanggung jawab sosial, maka tekanan terhadap manajemen juga akan semakin besar untuk mengungkapkannya (Sembiring, 2005). Dikaitkan dengan teori agensi bahwa semakin besar 
atau banyak jumlah dari dewan komisaris akan lebih memudahkan pelaksanaan tanggung jawab sosial perusahaan. Maka dari itu semakin rendah tingkat likuiditas dan semakin banyak ukuran dewan komisaris diharapkan dapat lebih luas mengungkapkan tentang tanggungjawab sosial dan lingkungan yang mereka lakukan (Kamil dan Antonius, 2012). Dapat disimpulkan hipotesis sebagai berikut:

\section{$\mathrm{H}_{5} \quad$ : Ukuran Dewan Komisaris secara signifikan dapat memoderasi hubungan antara pengaruh likuiditas terhadap pengungkapan Corporate Social Responsibility (CSR).}

\section{Pengaruh Ukuran Dewan Komisaris Sebagai Variabel Moderating dalam Hubungan Leverage dengan Corporate Social Responsibility (CSR)}

Perusahaan dengan rasio leverage yang tinggi memiliki besar kemungkinan untuk melakukan pelanggaran terhadap perjanjian kredit sehingga perusahaan akan berusaha melaporkan laba sekarang lebih tinggi. Manajer harus melakukan pengurangan biaya-biaya, termasuk biaya pengungkapan CSR, agar laba yang dilaporkan perusahaan lebih tinggi. Keterbatasan biaya CSR menjadikan pengungkapan informasi sosial menjadi rendah atau terbatas sehingga semakin tinggi leverage suatu perusahaan akan menambah beban tetap perusahaan yang menyebabkan rendahnya pengungkapan CSR karena terbatas (Rawi dan Muchlish, 2010). Menurut Sembiring (2005) tingkat leverage perusahaan dapat menggambarkan resiko keuangan perusahaaan. Sesuai dengan teori agensi manajemen perusahaan dengan tingkat leverage yang tinggi akan mengurangi pengungkapan tanggung jawab sosialnya agar tidak menjadi sorotan dari para debtholders. Dewan komisaris sebagai wakil dari shareholder dalam perusahaan memiliki wewenang yang dapat memberikan pengaruh yang kuat untuk menekan manajemen dalam mengungkapkan informasi tanggung jawab sosialnya. Oleh karena itu dengan adanya dewan komisaris dalam hubungan leverage dengan pengungkapan CSR diharapkan dapat memberikan pengaruh pada perusahaan untuk dapat mengungkapkan tanggung jawab sosialnya. Dapat disimpulkan hipotesis sebagai berikut:

\section{$\boldsymbol{H}_{6} \quad$ : Ukuran Dewan Komisaris secara signifikan dapat memoderasi hubungan antara pengaruh leverage terhadap pengungkapan Corporate Social Responsibility (CSR).}

\section{METODE PENELITIAN}

Populasi dalam penelitian ini adalah perusahaan manufaktur yang terdaftar di BEI pada tahun 2013-2016. Adapun alasan dari peneliti menggunakan perusahaan manufaktur yaitu karena perusahaan yang bergerak pada bidang manufaktur akan lebih banyak memiliki dampak bagi lingkungan sekitar perusahaan (Kamil dan Antonius, 2012). Metode pengambilan sampel pada penelitian ini yaitu metode purposive sampling dengan sampel yang digunakan sebanyak 182 perusahaan.

Penelitian ini menggunakan variabel dependen pengungkapan Corporate Social Responsibility (CSR) yang mana tingkat pengungkapan CSR pada laporan tahunan perusahaan manufaktur yang diukur dengan nilai (score) dari indeks CSR. Indeks CSR dalam penelitian ini merupakan indeks dari Global Reporting Initiative versi empat G4 (GRI G4). Analisis data menggunakan analisis isi dengan metode skoring berdasarkan GRI G4 yang terdiri dari 3 fokus pengungkapan, yaitu ekonomi, lingkungan dan sosial. Dari ketiga dimensi diperluas menjadi 6 dimensi yaitu ekonomi, lingkungan, praktek tenaga kerja, hak asasi manusia, masyarakat, dan tanggung jawab produk. Dari keenam dimensi tersebut terdapat 46 konstruk dan total seluruh item pengungkapan menurut $G R I$ adalah 91 item. Penilaian yang digunakan adalah sebagai berikut:

- Nilai 0 untuk setiap item yang tidak diungkapkan

- Nilai 1 untuk setiap item yang diungkapkan 
Apabila seluruh item telah diungkapkan maka nilai maksimal yang dapat dicapai adalah sebesar 91. Penelitian ini menggunakan tiga variabel independen yaitu profitabilitas, likuiditas, dan leverage. Profitabilitas diukur menggunakan Return On Asset (ROA) yaitu mengukur kemampuan perusahaan dalam menghasilkan laba atau profit dengan menggunakan total aktiva. Likuiditas dikukur menggunakan Rasio Lancar yang mengukur kemampuan perusahaan dalam membayar hutang jangka pendeknya. Leverage diukur menggunakan Debt Equity Ratio (DER) yang mengukur seberapa besar perusahaan bergantung pada kreditur dalam melakukan pembiayaan terhadap aset perusahaannya. Penelitian ini juga menggunakan variabel moderasi yaitu ukuran dewan komisaris yang mana diukur dengan menjumlahkan total seluruh anggota dewan komisaris didalam perusahaan.

\begin{tabular}{lc}
\hline Variabel & Rumus \\
\hline Return On Asset (ROA) & ROA $=\frac{\text { Laba bersih setelah pajak }}{\text { Total aktiva }}$ \\
Rasio lancar & Rasio Lancar $=\frac{\text { Aktiva Lancar }}{\text { Hutang Lancar }}$ \\
Debt Equity Ratio (DER) & Debt Equity Ratio $($ DER $)=$ \\
& $\frac{\text { Total kewajiban }}{\text { ekuitas pemegang saham }}$ \\
Ukuran Dewan Komisaris & UDK $=\Sigma$ Dewan Komisaris \\
\hline
\end{tabular}

Penelitian ini menggunakan regresi berganda. Bentuk persamaan dalam penelitian ini adalah:

Model Regresi $\mathbf{H}_{1}, \mathbf{H}_{2}$, dan $\mathbf{H}_{3}$

$\mathbf{C S R}=\alpha+\beta_{I} P R O F+\beta_{2} L I K+\beta_{3} L E V+e$

Model Regresi $\mathbf{H}_{4}, \mathbf{H}_{5}$, dan $\mathbf{H}_{6}$

CSR $=\alpha+\beta_{l} P R O F+\beta_{2} L I K+\beta_{s} L E V+\beta_{i} U D K+\beta_{s} P R O F . U D K+\beta_{b} L I K . U D K+\beta_{7} L E V . U D K$ $+e$

Keterangan:

CSR : Pengungkapan Corporate Social Responsibility

$\alpha \quad$ : Konstanta

$\beta_{1-} \beta_{7} \quad$ : Koefisien Regresi

PROF : Profitabilitas

LIK : Likuiditas

LEV : Leverage

UDK : Ukuran Dewan Komisaris

e : error

\section{HASIL DAN PEMBAHASAN}

\section{Analisis Statistik Deskriptif}

Hasil analisis deskriptif pada penelitian ini disajikan dalam tabel berikut: 
Tabel 1. Hasil Uji Statistik Deskriptif

\begin{tabular}{llllll}
\hline & N & Minimum & Maximum & Mean & Std. Deviation \\
\hline PROF & 182 & $7,57194 \mathrm{E}-4$ &, 90872 &, 1056808 &, 10398602 \\
LIK & 182 &, 40314 & 15,16460 & 3,0370722 & 2,50456676 \\
LEV & 182 &, 07088 & 7,39644 &, 8346510 &, 99089603 \\
CSR & 182 &, 05495 &, 51648 &, 3026205 &, 09660870 \\
UDK & 182 & 2 & 12 & 4,56 & 1,987 \\
PROF.UDK & 182 & .00 & 4.54 & .4955 & .54875 \\
LIK.UDK & 182 & .81 & 64.97 & 13.4373 & 11.06560 \\
LEV.UDK & 182 & .21 & 28.63 & 3.6018 & 3.79656 \\
Valid N (listwise) & 182 & & & & \\
\hline
\end{tabular}

\section{Uji Normalitas}

Hasil uji normalitas disajikan dalam tabel berikut:

Tabel 2. Hasil Uji Normalitas

\begin{tabular}{lll}
\hline & & Unstadardized Residual \\
\hline N & & 182 \\
& Mean & .0000000 \\
Most Extreme Differences & Std. Deviation & .09329603 \\
& Absolute & .044 \\
& Positive & .025 \\
Kolmogorov-Smirnov Z & Negative & -.044 \\
Asymp.Sig. (2-tailed) & & .594 \\
\hline
\end{tabular}

Hasil uji normalitas yang menggunakan uji statistik Kolmogorov-Smirnov (K-S) menunjukkan bahwa data yang digunakan berdistribusi normal. Berdasarkan tabel diatas dapat dilihat dari nilai Asymp Sig (2-tailed) sebesar 0,872 yang melebihi besar nilai alpha yaitu 0,05. Berdasarkan hasil dari pengujian ini dapat disimpulkan bahwa model regresi dalam penelitian ini memenuhi asumsi normalitas.

\section{Uji Autokorelasi}

Hasil uji autokorelasi disajikan dalam tabel berikut:

Tabel 3. Hasil Uji Autokorelasi

\begin{tabular}{ll}
\hline & Unstandardized Residual \\
\hline Test Value & .00698 \\
Cases < Test Value & 91 \\
Cases $>=$ Test Value & 91 \\
Total Cases & 182 \\
Number of Runs & 86 \\
Z & -.892 \\
Asymp.Sig. (2-tailed) & .372 \\
\hline
\end{tabular}

Pada hasil pengujian tabel 3 menunjukkan bahwa nilai Asymp.Sig. (2-tailed) yang dihasilkan sebesar 0,372. Hal ini menunjukkan bahwa data tidak terdapat autokorelasi karena nilai asymp.sig $(2$-tailed) $0,372>$ alpha 0,05 .

\section{Uji Multikolonearitas}

Hasil uji multikolinearitas disajikan dalam tabel sebagai berikut: 
Tabel 4. Hasil Uji Multikolinearitas

\begin{tabular}{lll}
\hline Model & \multicolumn{2}{l}{ Collinearity Statistics } \\
\cline { 2 - 3 } (Constant) & Tolerance & VIF \\
PROF & & \\
LIK & .977 & 1.023 \\
LEV & .831 & 1.203 \\
\hline
\end{tabular}

Pada pengujian ini menunjukkan bahwa pada variabel profitabilitas memiliki nilai tolerance sebesar $0,977>$ nilai alpha 0,05 dan nilai VIF sebesar $1,023<10$ yang berarti tidak terjadi multikolinearitas. Nilai tolerance dan VIF pada variabel likuiditas masing-masing memiliki nilai $0,831>$ alpha 0,05 dan 1,203 < 10 yang berarti tidak terjadi mutikolinearitas. Variabel leverage memiliki nilai tolerance dan VIF masing-masing $0,840>$ nilai alpha 0,05 dan $1,190<10$ yang berarti tidak terjadi multikolinearitas. Maka dari hasil pengujian dapat disimpulkan bahwa tidak terjadi multikolinearitas pada persamaan regresi yang digunakan.

\section{Uji Heteroskedastisitas}

Hasil uji heteroskedastisitas disajikan dalam tabel berikut:

Tabel 5. Hasil Uji Heteroskedastisitas

\begin{tabular}{ll}
\hline Model & Sig. \\
\hline (Constant) & .000 \\
PROF & .650 \\
LIK & .784 \\
LEV & .591 \\
\hline
\end{tabular}

Pada penelitian ini dapat dilihat bahwa pada variabel profitabilitas nilai sig sebesar 0,650 > nilai alpha 0,05 yang berarti tidak terjadi Heteroskedastisitas. Pada variabel likuiditas nilai sig 0,784 $>$ nilai alpha 0,05 berarti tidak terjadi Heteroskedastisitas. Variabel leverage memiliki nilai sig 0,591 $>$ nilai alpha 0,05 yang berarti tidak terjadi Heteroskedastisitas. Hasil uji Heteroskedastisitas ini dapat disimpulkan bahwa tidak terjadi Heteroskedastisitas dalam regresi ini.

\section{Uji Koefisien Determinasi ( $\left.\mathbf{R}^{2}\right)$}

Hasil uji koefisien determinasi disajikan dalam tabel berikut:

Tabel 6. Hasil Uji Koefisien Determinasi

\begin{tabular}{llll}
\hline Model & R Square & Adjusted R Square & Std. Error of the Estimate \\
\hline 1 & .067 & .052 & .09407894 \\
\hline
\end{tabular}

Berdasarkan tabel tersebut hasil pengujian yang didapatkan yaitu besar koefisien determinasi (Adjusted $R$ Square) sebesar 0,067. Berdasarkan hasil tersebut menunjukkan bahwa variabel pengungkapan Corporate Social Responsibility (CSR) dapat dijelaskan oleh variabel-variabel independen sebesar $6,7 \%$ dan sisanya sebesar $93,3 \%$ dijelaskan oleh faktor-faktor yang lain diluar penelitian.

\section{Uji Nilai $F$}

Hasil uji $\mathrm{F}$ disajikan dalam tabel berikut:

Tabel 7. Hasil Uji F

\begin{tabular}{lll}
\hline Model & F & Sig. \\
\hline Regression & 4.288 & $.006^{\mathrm{a}}$ \\
Residual & & \\
Total & & \\
\hline
\end{tabular}


Pada tabel tersebut menunjukkan bahwa nilai $\mathrm{F}$ sebesar 4,288 dengan nilai signifikansi sebesar 0,006 < nilai alpha 0,05 berarti dapat disimpulkan bahwa variabel independen secara simultan berpengaruh signifikan terhadap variabel dependen.

\section{Hasil Penelitian (Pengujian Hipotesis)}

Hasil uji t sebelum moderasi disajikan dalam tabel berikut:

Tabel 8. Hasil Uji t (Sebelum Moderasi)

\begin{tabular}{llll}
\hline Model & B & Beta & Sig. \\
\hline (Constant) & .308 & & .000 \\
PROF & .097 & .104 & .157 \\
LIK & .001 & .021 & .787 \\
LEV & -.021 & -.217 & .007 \\
\hline
\end{tabular}

\section{a. Pengaruh Profitabilitas Terhadap Pengungkapan Corporate Social Responsibility (CSR)}

Hasil pengujian hipotesis menunjukkan bahwa profitabilitas tidak berpengaruh terhadap pengungkapan CSR. Hal ini terbukti dari nilai sig sebesar 0,157> alpha 0,05 dan koefisien beta sebesar 0,097. Sehingga hipotesis pertama $\left(\mathrm{H}_{1}\right)$ yang menyatakan bahwa profitabilitas berpengaruh positif dan signifikan terhadap pengungkapan CSR ditolak. Hasil penelitian ini tidak mendukung teori legitimasi, karena perusahaan dengan profitabilitas yang tinggi menganggap bahwa perusahaan itu tidak perlu untuk melaporkan tentang tanggung jawab sosialnya.

Selain hal tersebut perusahaan dengan tingkat profitabilitas yang rendah akan lebih memilih menggunakan labanya untuk kegiatan operasional perusahaan, oleh karenanya pemanfaatan untuk pengungkapan tanggung jawab sosial lebih sedikit. Sehingga pengungkapan tanggung jawab sosial ini tidak lagi dipengaruhi oleh besar kecilnya profitabilitas karena perusahaan sadar akan pentingnya pengungkapan tanggung jawab sosial yang harus dilakukan oleh perusahaan.

Hasil dari penelitian ini mendukung penelitian Putri dan Christiawan (2014) yang menunjukkan hasil bahwa profitabilitas tidak memiliki pengaruh terhadap pengungkapan CSR. Penelitian ini juga didukung oleh Sulistyawati et. al (2016) yang menunjukkan hasil bahwa profitabilitas tidak memiliki pengaruh terhadap pengungkapan CSR.

\section{b. Pengaruh Likuiditas Terhadap Pengungkapan Corporate Social Responsibility (CSR)}

Hasil dari pengujian hipotesis kedua ini membuktikan bahwa likuiditas tidak berpengaruh terhadap pengungkapan CSR. Hal ini terbukti dari nilai sig sebesar 0,787 > alpha 0,05 dan koefisien beta sebesar 0,001 . Sehingga hipotesis kedua $\left(\mathrm{H}_{2}\right)$ yang menyatakan likuiditas berpengaruh positif dan signifikan terhadap pengungkan CSR ditolak. Hal tersebut berarti bahwa besar kecilnya tingkat likuiditas tidak berpengaruh terhadap tingkat pengungkapan Corporate Social Responsibility. Perusahaan yang memiliki tingkat likuiditas yang rendah akan lebih fokus untuk melunasi hutanghutangnya daripada perusahaan tersebut harus mengungkapkan kegiatan tanggung jawab sosial perusahaan yang akan mengurangi kemampuan perusahaan dalam melunasi hutang-hutangnya.

Sedangkan perusahaan yang memiliki tingkat likuiditas tinggi menandakan bahwa perusahaan tersebut memiliki kinerja finansial yang baik, sehingga perusahaan merasa tidak perlu untuk melakukan pengungkapan tanggung jawab sosial dalam laporan tahunan karena hal tersbut dianggap tidak memiliki pengaruh terhadap investor. Sehingga tingkat pengungkapan tanggung jawab sosial tidak lagi dipengaruhi oleh besar kecilnya tingkat likuiditas perusahaan.

Penelitian ini sejalan dengan penelitian yang dilakukan oleh Putri dan Christiawan (2014) yang menunjukkan hasil bahwa likuiditas tidak memiliki pengaruh terhadap pengungkapan CSR. Hasil penelitian ini juga sejalan dengan penelitian yang dilakukan oleh Ekowati et. al (2014) yang memberikan hasil bahwa likuiditas tidak berpengaruh terhadap pengungkapan CSR. 


\section{c. Pengaruh Leverage Terhadap Pengungkapan Corporate Social Responsibility (CSR)}

Hasil dari pengujian hipotesis ketiga ini membuktikan bahwa leverage memiliki pengaruh negatif terhadap pengungkapan CSR. Hal ini terbukti dari nilai sig sebesar 0,007 < alpha 0,05 dan koefisien beta sebesar $-0,021$. Sehingga hipotesis ketiga $\left(\mathrm{H}_{3}\right)$ yang menyatakan leverage berpengaruh negatif terhadap pengungkapan CSR diterima. Hal tersebut berarti semakin besar tingkat leverage, maka semakin sedikit pengungkapan tanggung jawab sosial yang dilakukan perusahaan. Perusahaan dengan tingkat leverage yang tinggi maka kemungkinan besar perusahaan akan melakukan pelanggaran terhadap perjanjian kredit sehingga perusahaan akan berusaha untuk melaporkan laba sekarang lebih tinggi. Perusahaan akan melakukan pengurangan biaya-biaya termasuk biaya untuk melakukan pengungkapan CSR agar laba yang dilaporkan lebih tinggi (Belkaoui dan Karpik, 1989). Penelitian ini mendukung teori agensi, yang menyatakan bahwa tingkat leverage mempunyai pengaruh negatif terhadap pengungkapan CSR. Manajemen perusahaan dengan tingkat leverage tinggi cenderung mengurangi pengungkapan tanggung jawab sosialnya agar tidak menjadi sorotan para debtholders.

Penelitian ini sejalan dengan penelitian Anugerah et. al (2010) yang menunjukkan hasil bahwa leverage berpengaruh negatif terhadap pengungkapan CSR Hasil penelitian ini juga sejalan dengan penelitian Kurniawati (2013) yang menunjukkan hasil bahwa leverage berpengaruh negatif terhadap pengungkapan CSR.

\section{Hasil Uji t setelah moderasi disajikan dalam tabel berikut:}

Tabel 9. Hasil Uji t (Setelah Moderasi)

\begin{tabular}{llll}
\hline Model & $\mathrm{B}$ & Beta & Sig. \\
\hline (Constant) & .207 & & .000 \\
PROF & -.053 & -.057 & .864 \\
LIK & .009 & .242 & .313 \\
LEV & .011 & .109 & .725 \\
UDK & .022 & .010 & .033 \\
PROF.UDK & .029 & .163 & .647 \\
LIK.UDK & -.002 & -.207 & .435 \\
LEV.UDK & -.008 & -.304 & .352 \\
\hline
\end{tabular}

\section{d. Pengaruh Ukuran Dewan Komisaris sebagai Variabel Moderating dalam Hubungan Profitabilitas terhadap Pengungkapan Corporate Social Responsibility (CSR)}

Berdasarkan hasil dari pengujian hipotesis keempat membuktikan hasil bahwa ukuran dewan komisaris tidak mampu memoderasi hubungan antara profitabilitas dengan pengungkapan CSR. Hal ini terbukti dari nilai sig sebesar 0,647> alpha 0,05. Sehingga hipotesis keempat $\left(\mathrm{H}_{4}\right)$ yang menyatakan ukuran dewan komisaris secara signifikan dapat memoderasi hubungan antara pengaruh profitabilitas terhadap pengungkapan CSR ditolak. Hal ini berarti semakin tinggi tingkat profitabilitas dan semakin besar jumlah dewan komisaris pada perusahaan tidak mempengaruhi perusahaan dalam melakukan pengungkapkan Corporate Social Responsibility (CSR). Dengan adanya ukuran dewan komisaris ini tidak mampu memperkuat hubungan antara profitabilitas dengan CSR. Hasil dari pengujian hipotesis ini tidak sejalan dengan teori agensi yang mengemukakan bahwa semakin besar atau semakin banyaknya jumlah dewan komisaris akan lebih memudahkan pelaksanaan tanggung jawab sosial perusahaan.

\section{e. Pengaruh Ukuran Dewan Komisaris sebagai Variabel Moderating dalam Hubungan Likuiditas terhadap Pengungkapan Corporate Social Responsibility (CSR)}

Berdasarkan hasil pengujian hipotesis kelima membuktikan hasil bahwa ukuran dewan komisaris tidak mampu memoderasi hubungan antara likuiditas dengan pengungkapan CSR. Hal ini terbukti dari nilai sig sebesar 0,435 > alpha 0,05. Sehingga hipotesis kelima yang menyatakan 
ukuran dewan komisaris secara signifikan dapat memoderasi hubungan antara pengaruh likuiditas terhadap pengungkapan CSR ditolak. Hal ini berarti semakin tinggi tingkat likuiditas dan semakin besar jumlah dewan komisaris pada perusahaan tidak mempengaruhi perusahaan dalam melakukan pengungkapkan Corporate Social Responsibility (CSR). Dengan adanya ukuran dewan komisaris ini tidak mampu memperkuat hubungan antara likuiditas dengan CSR. Hasil dari pengujian hipotesis ini tidak sejalan dengan teori agensi yang mengemukakan bahwa semakin besar atau semakin banyaknya jumlah dewan komisaris akan lebih memudahkan pelaksanaan tanggung jawab sosial perusahaan.

\section{f. Pengaruh Ukuran Dewan Komisaris sebagai Variabel Moderating dalam Hubungan Leverage terhadap Pengungkapan Corporate Social Responsibility (CSR)}

Berdasarkan hasil dari pengujian hipotesis keenam membuktikan hasil bahwa ukuran dewan komisaris tidak mampu memoderasi hubungan antara leverage dengan pengungkapan CSR. Hal ini terbukti dari nilai sig sebesar 0,352 > alpha 0,05. Sehingga hipotesis keenam $\left(\mathbf{H}_{6}\right)$ yang menyatakan ukuran dewan komisaris secara signifikan dapat memoderasi hubungan antara pengaruh leverage terhadap pengungkapan CSR ditolak. Hal ini berarti semakin tinggi ukuran dewan komisaris tidak dapat mempengaruhi perusahaan untuk melakukan pengungkapan tanggung jawab sosial. Dengan adanya ukuran dewan komisaris ini tidak mampu memperkuat hubungan antara leverage dengan CSR. Hasil dari pengujian hipotesis ini tidak sejalan dengan teori agensi yang mengemukakan bahwa semakin besar atau semakin banyaknya jumlah dewan komisaris akan lebih memudahkan pelaksanaan Corporate Social Responsibility (CSR).

\section{KETERBATASAN PENELITIAN}

Adapun keterbatasan dalam penelitian ini yaitu variabel independen yang digunakan hanya profitabilitas, likuiditas, dan leverage. Sampel yang digunakan hanya perusahaan manufaktur. Tahun penelitian yang digunakan hanya 4 tahun. Jumlah sampel yang digunakan hanya 182 sampel

\section{KESIMPULAN}

Penelitian ini meneliti pengaruh profitabilitas, likuiditas, dan leverage terhadap pengungkapan Corporate Social Responsibility (CSR) dengan ukuran dewan komisaris sebagai variabel moderasi. Variabel dependen dalam penelitian ini diukur dengan menggunakan ceklist pengungkapan corporate social responsibility berdasarkan GRI versi G4.

Hasil pengujian dari penelitian ini menunjukkan profitabilitas tidak berpengaruh positif terhadap pengungkapan CSR. Likuiditas tidak berpengaruh positif terhadap pengungkapan CSR. Leverage berpengaruh negatif terhadap pengungkapan CSR. Ukuran dewan komisaris tidak dapat memoderasi hubungan antara profitabilitas terhadap pengungkapan CSR. Ukuran dewan komisaris tidak dapat memoderasi hubungan antara likuiditas terhadap pengungkapan CSR. Ukuran dewan komisaris tidak dapat memoderasi hubungan antara leverage terhadap pengungkapan CSR.

Saran yang dapat diberikan untuk peneliti selanjutnya yaitu peneliti selanjutnya diharapkan dapat menambah variabel lain yang dimungkinkan dapat berpengaruh terhadap pengungkapan CSR. Disarankan peneliti selanjutnya menggunakan sampel lain untuk penelitian selanjutnya yaitu perusahaan dagang, perusahaan pertambangan dan yang lainnya selain perusahaan manufaktur. Memperpanjang tahun penelitian. Menggunakan alat pengukuran lain untuk mengukur variabel independen maupun dependen 


\section{DAFTAR PUSTAKA}

Anggraini, R. (2006). Pengungkapan Informasi Sosial dan Faktor-Faktor Yang Mempengaruhi Pengungkapan Informasi Sosial Dalam Laporan Keuangan Tahunan (Studi Empiris pada Perusahaan-Perusahaan yang Terdaftar Bursa Efek Jakarta). Simposium Nasional Akuntansi 9. Padang.

Anugerah, R., Hutabarat, R., Faradilla, W. (2010). Pengaruh Ukuran Perusahaan, Leverage, dan Profitabilitas terhadap Pengungkapan Tanggung Jawab Sosial Perusahaan pada Perusahaan Manufaktur yang Listing di BEI. Jurnal Ekonomi, 18, (1).

Arlindania, P. A., \& Sudana, I. M. (2011). Corporate Governance dan Pengungkapan Corporate Social Responsibility pada Perusahaan Go Public di Bursa Efek Indonesia. Jurnal Manajemen Teori dan Terapan, 4 (1).

Badjuri, A. (2011). Faktor-faktor Fundamental, Mekanisme Corporate Governance, Pengungkapan Corporate Social Responsibility (CSR). Perusahaan Manufaktur dan Sumber Daya Alam di Indonesia. Dinamika Keuangan dan Perbankan.

Belkaoui, A. \& P. G. Karpik. (1989). Determinants of the Corporate Decision to Disclose Social Information. Accounting, Auditing and Accountability Journal. 2. (1), 36-51.

Daniri, M. A. (2008). Standarisasi Tanggung Jawab Sosial Perusahaan (BagI). http://www.madaniri.com/2008/01/17/standarisasi-tanggung-jawab-sosialperusahaan-bag-i/. Diakses tanggal 5 Juni 2008.

Ekowati, L., Prasetyono \& Wulandari, A. (2014). Pengaruh Profitabilitas, Likuiditas, Growth, dan Media Exposure Terhadap Pengungkapan Tanggungjawab Sosial Perusahaan. Simposium Nasional Akuntansi XVII.

Fahrizqi, A. (2010). Faktor-Faktor yang Mempengaruhi Pengungkapan Corporate Social Responsibility (CSR) dalam Laporan Tahunan Perusahaan (Studi Empiris pada Perusahaan Manufaktur yang Terdaftar Dalam Bursa Efek Indonesia). Skripsi. Semarang. Program Sarjana Fakultas Ekonomi Universitas Diponegoro.

Gray, R., Javad, M., \& David, M. (2001). Social and Environmental Disclosure, and Corporate Characteristic: A Research Note and Extension. Accounting, Auditing, and Accountability Journal 28 (3), 327-356.

Kamil, A. \& Antonius, H. (2012). Pengaruh Karakteristik Perusahaan terhadap Luas Pengungkapan Kegiatan Corporate Social Responsibility.

Kinantika, E. K. A. (2013). Pengaruh Biaya Eksplorasi dan Pengembangan Tangguhan, Leverage, dan Profitabilitas terhadap Luas Pengungkapan Corporate Social Responsibility. Semarang. Fakultas Ekonomi dan Bisnis Universitas Diponegoro.

Kurniawati, F. A. (2013). Pengaruh Profitabilitas, Leverage, dan Ukuran Perusahaan terhadap Luas Pengungkapan Tanggung Jawab Sosial Perusahaan Pertambangan di Bursa Efek Indonesia (BEI) Periode 2009-2011. Skripsi. Yogyakarta. Universitas Negeri Yogyakarta.

Marbun, D. B. (2008). Analisis Faktor-faktor Yang Mempengaruhi Pengungkapan Tanggung Jawab dan Akuntansi Sosial Perusahaan (Corporate Responsibility and Social Accounting): Studi Empiris Pada Perusahaan Yang Terdaftar di Bursa Efek Indonesia. Skripsi. Universitas Riau. Pekanbaru

Nurkhin, A. (2010). Corporate Governance dan Profitabilitas, Pengaruhnya Terhadap Pengungkapan CSR Perusahaan. Jurnal Dinamika Akuntansi, 2 (1).

Putri, R. A. \& Christiawan, Y. J. (2014). Pengaruh Profitabilitas, Likuiditas, dan Leverage terhadap Pengungkapan Corporate Social Responsibility (CSR). Business Accounting Review, 2 (1).

Rawi \& Munawar, M. (2010). Kepemilikan Manajemen, Kepemilikan Institusi, Leverage dan Corporate Social Responsibility. Simposium Nasional Akuntansi XIII. Purwokerto.

Rosmasita. (2007). Faktor-faktor yang Mempengaruhi Pengungkapan Sosial (Social Disclosure) dalam Laporan Keuangan Tahunan Perusahaan Manufaktur di Bursa Efek Jakarta. Simposium Nasional Akuntansi X. Makasar. 
Sembiring, E. R. (2005). Karakteristik Perusahaan dan Pengungkapan TanggungJawab Sosial: Studi Empiris pada Perusahaan yang Tercatat di Bursa Efek Jakarta. Simposium Nasional Akuntansi 8. Solo.

Sulistyawati, A. I., Surjanti, L. P. N. S. \& Triyani, D. (2016). Pengungkapan Corporate Social Responsibility pada Laporan Keuangan dan Determinasinya. Seminar Nasional IENACO.

Sumarsan, T. (2010). Sistem Pengendalian Manajemen (Konsep, Aplikasi dan Pengukuran Kinerja). Jakarta: Indeks.

Syahrir, R. K. \& Sehendra S. (2010). The Effect of Company Characteristic to Disclosure Fittings of Miscellanous Industry Sector Annual Reports Which is Registered in IDX. Tesis. Universitas Gunadarma.

Undang-Undang No. 25 Tahun 2007 tentang Penanaman Modal

Undang-Undang No. 40 Tahun 2007 Pasal 1 Ayat 3

Undang-Undang No. 40 Tahun 2007 Pasal 73 tentang Perseroan Terbatas.

Warta Ekonomi. (2006). Konsep Bisnis Paling Bersinar 2006: Level Adopsinya Kian Tinggi, Warta Ekonomi, Desember 2006, 36-37.

Yintayani, N. N. (2011). Faktor-Faktor yang Mempengaruhi Corporate Social Responsibility (CSR) (Studi Empiris pada Perusahaan yang Terdaftar Di Bursa Efek Indonesia Tahun 2009). Tesis. Denpasar. Program Magister Fakultas Ekonomi Pascasarjana Universitas Udayana. 